\title{
DYNAMICS OF SOIL CARBON AND N, P, K NUTRIENTS ON CORN PLANTING PATTERN IN DRY LAND
}

\author{
Rupa Matheus $^{1 *}$, Laurensius Lehar ${ }^{2}$, IGA. Mas Sri Agung ${ }^{3}$ \\ ${ }^{1}$ Agricultural Extension Study Program, State Agricultural Polytechnic of Kupang, Indonesia \\ ${ }^{2}$ Horticultural Industry Technology Study Program, State Agricultural Polytechnic of Kupang, \\ Indonesia \\ ${ }^{3}$ Agricultural Science Study Program, Postgraduate Program Udayana University Denpasar, Indonesia. \\ *Corresponding Author: matheusrupa@yahoo.com.
}

\begin{abstract}
A study was conducted during two planting seasons, namely planting season 1 (PS-1) 2017/2018 and (PS-2): 2018/2019, in Oelnasi Village, Central Kupang sub-district, Kupang District, East Nusa Tenggara, Indonesia. This study aimed to evaluate the rotation pattern of maize with legumes ground covers towards the dynamics of soil carbon and nutrients $\mathrm{N}, \mathrm{P}, \mathrm{K}$ during the two growing seasons in a dryland farming system. The experiment was designed using a randomized block design with 3 (three) treatments replicated five times. The treatments evaluated were: crop rotation patterns consisting of: without rotation (farmer practice) and rotation pattern with Phaseolus lunatus; rotation pattern with Mucuna pruriens. Legume crops planted after harvesting the food crop and allowed to grow during the dry season. Approaching the rainy season, the biomass of the legume crop is returned to the land by immersing them it together with soil cultivation. Chemical fertilizers is given as an independent variables with a dose of $150 \mathrm{~kg} / \mathrm{ha}$ of Urea; $100 \mathrm{~kg} / \mathrm{ha}$ of SP36 and $100 \mathrm{~kg} / \mathrm{ha}$ of KCL. The results showed that the rotation pattern of Mucuna pruriens significantly increased the soil organic $\mathrm{C}$ content by $50.56 \%$ and legume Phaseolus lunatus by $37.64 \%$ to PS-2. The rotation pattern of the legume covers / covered crop also significantly increased the efficiency of agronomic nutrients $(\mathrm{N}, \mathrm{P}$, and K nutrients) and maize yields during the two growing seasons. On the other hand, the farmer pattern (without rotation) showed a decrease in soil carbon to PS-2 which of course affect the efficiency of nutrient absorption.
\end{abstract}

Keywords: Carbon and nutrient dynamics; Agronomic nutrient efficiency; Crop rotation pattern; Ground cover legumes.

\section{INTRODUCTION}

In general, the productivity of dry land farming in the district of Kupang, East Nusa Tenggara, Indonesia is relatively low compared to farming in wetlands. The main causes are the relatively low soil quality factor and relatively short (3-4 wet months) rainfall distribution, (Matheus, 2014). Currently, many productive agricultural lands have been degraded due to intensive farming patterns of continuous planting patterns, besides erosion factors that cause a decrease in soil organic carbon (C) levels as an indicator of soil quality. It is reported that the soil organic carbon (C) contented of most agricultural land in Indonesia in the last three decades has reached a low level of $<2 \%$ for wetlands, even for dry land <1.67\% (Matheus et al., 2018). 
The agricultural system can be sustainable if the soil organic $\mathrm{C}$ content is more than $2 \%$ (Handayanto, 1999). The solution to making dry land farming more productive requires an increase in soil organic carbon $(\mathrm{C})$ as an important soil constituent component.

Soil organic carbon $(\mathrm{C})$ is one of the main indicators of soil quality (Doran and Parkin 1994; Larson and Pierce 1994; Islam and Weil, 2000), because of its role in determining the physical, chemical, and biological properties of the soil (Olson et al. 2010; Liu et al. 2006). The soil has a high potential for carbon sequestration because it can contribute to agronomic, physiological efficiency, and is important in the recovery of nitrogen, phosphorus, and potassium (Rahman, 2013). In addition, carbon (C) soil, can increase the efficiency of fertilization.

Apart from organic $\mathrm{C}$, macro nutrients of $\mathrm{N}, \mathrm{P}$, and $\mathrm{K}$ are essentially needed by plants in large quantities, so their availability in the soil must be considered. The fulfillment is through fertilization, but the level of fertilization efficiency is generally still low (Finck, 1992; Kasno and Rostaman, 2013). The low uptake of fertilizer nutrients by plants is due to the low levels of organic $\mathrm{C}$ in the soil, thus affecting the mineralization process of available nutrients in the soil solution.

The habit of dry land farmers, who often carry out a continuous monoculture cropping pattern and do not return crop residues after harvest to the land, has contributed to carbon and nutrient mining and imbalance of essential nutrients, which in the end it will disrupt the productivity of food crops on dry land. To ensure that quality is maintained, land management and fertilization actions are required based on plant nutrient needs by taking into account the dynamics of carbon and nutrients in the soil.

Therefore, to ensure that soil quality levels are maintained, land management measures through crop residue management are needed, namely by implementing a food crop rotation pattern with legume ground covers during the fallow period. Through land covered by legume plant biomass during the fallow period, the physical condition of the soil is maintained in a sustainable manner (Matheus, 2019). This rotation pattern is suitable for dry land farmers because it is easy and cheap, compared to using manure which is more expensive. The rotation pattern of the legume ground covers can contribute biomass as a source of carbon as well as that of natural nitrogen (Matheus, 2014). This study aims to determine the rotation pattern of the legume ground covers and their residual effects on the dynamics of soil organic carbon, N, P, K nutrients, and corn yields during the two growing seasons. 


\section{MATERIALS AND METHODS}

\section{Study area}

Field trials were carried out on land owned by farmers in Oelnasi Village, Central Kupang sub-district, Kupang District, East Nusa Tenggara, Indonesia. Field trials implemented during for 2 (two) years, namely: planting season 1 (PS-1) 2017/2018 and (PS-2): 2018/2019. The type of soil in the experimental site was belonged in the ultisol order cambisol soil type. The climate is tropical with a total rainfall of $1500 \mathrm{~mm} / \mathrm{year}$ and an average annual temperature of $29^{\circ} \mathrm{C}$. The experiment site was dry land that was cultivated continuously and previously planted with corn.

\section{Design of experiments}

This study was designed as randomized block (RBD), with a single treatment of the land rotation pattern consisted of without rotation (farmer practiced); rotation pattern with Phaseolus lunatus; rotation pattern with Mucuna pruriens. The treatments was repeated 5 (five) times, which made the total of 15 experimental units. The legume ground covers were planted before the corn crop harvested and allowed to grow for 7 months (April-October 2017). Furthermore, before the legume ground covers biomass in each experimental plot was harvested, they were cut into pieces of $3-5 \mathrm{~cm}$ long, and returned (immersion method) into the experimental plot during soil cultivation. Corns, that were used as the indicator plants in this study, were planted during two growing seasons. Fertlizers at a rate of $150 \mathrm{~kg} / \mathrm{ha}$ of Urea, $100 \mathrm{~kg} / \mathrm{ha}$ of SP36, and $100 \mathrm{~kg} / \mathrm{ha}$ of $\mathrm{KCL}$, were applied to support the growth of corn plants.

Observations of soil and plant samples were carried out during two growing seasons, namely the rainy season (PS-1 and in the dry season (PS-2), to determine the effect of rotation patterns with the legume cover crops on the dynamics of carbon and NPK nutrients and corn yields. Soil samples were taken from three points at a depth of $0-30 \mathrm{~cm}$ in five replicates in each experimental plot and analyzed in the laboratory. Those samples were taken three times, namely at planting PS1 (after rotation); the end of the PS- 1 trial, and the end of the PS-2 trial. The parameters observed in this study were: (1). Soil properties, including C-organic (Walkley \& Black); total-N nutrient (Kjeldahl); AvailableP (Bray I), K (Acetic Acid 1M pH 7); (3) agronomic nutrient efficiency, namely comparing the amount of nutrients transported by plants with the amount of nutrients from fertilizers added ((Jagadeeswaran et al., 2005 and Milkha et al., 200; (4) corn yields (harvested dry kernels). 


\section{Statistical Analysis}

Data analysis was performed statistically using analysis of variance (ANOVA) or variance test, with a $95 \%$ confidence interval. To observe the effect of significant differences from the variables due to treatment, Duncan's multiple distance test was carried out at the 5\% real level (Gomez and Gomez, 2007). Data processing was performed using the Costat statistical program.

\section{RESULTS AND DISCUSSION RESULT}

The type of soil in the experimental location was belonged to the cambisol soil type, vertisol order, at an altitude of $440 \mathrm{~m}$ asl with flat topography $(+5 \%)$. The results of the analysis of the soil used in the research area are presented in Table 1.

The results of preliminary soil analysis showed that the soils in the study location was belong to the ultisol order, with high (68.54\%) clay content and the slope of $5 \%$, could cause poorl drainage of the soil. Soil organic-C, available-P, potential and available-K were classified low, which probably due to farmers do not usually apply $\mathrm{KCl}$ fertilizer to plants and very little plant residues are returned to the soils.

Table 1 Chemical and physical properties of soil in the experimental location in Oelnasi village, Central Kupang district, Kupang

\begin{tabular}{lllll}
\hline No & Parameter & Unit & Value & Description * \\
\hline 1 & Texture & $\%$ & & \\
& Sand & $\%$ & 10.52 & Clay \\
& Silt & $\%$ & 20.94 & \\
& Clay & - & 68.54 & Netral \\
2 & pH (H2O) & $\%$ & 7.57 & Low \\
3 & C (Walkley \& Black) & $\%$ & 1.87 & Low \\
4 & N (Kjeldahl) & - & 0.15 & Moderate \\
5 & C/N & Ppm & 13.13 & Low \\
6 & P2O5 (available-P) & mg 100g-1 & 6.55 & Low \\
7 & K2O (HCl 25\%) & $c m o l(+) \mathrm{kg}^{-1}$ & 6.59 & Moderate \\
8 & Ca-dd & $c m o l(+) \mathrm{kg}^{-1}$ & 0.79 & Low \\
9 & Mg-dd & $c m o l(+) \mathrm{kg}^{-1}$ & 0.17 & Low \\
10 & K-dd & cmol $(+) \mathrm{kg}^{-1}$ & 19.84 & Moderate \\
11 & CEC & & & \\
\hline
\end{tabular}

*) Sulaeman et al., 2005

\section{Dynamics of Soil Organic Carbon}

Observation of post-rotation soil organic carbon with legume ground covers is important because soil organic carbon is the main indicator of soil quality. This measurement is to determine whether there is any influence of the biomass residue of the legume ground covers the soil organic $\mathrm{C}$ 
content until the second planting season. Soil samples were taken at a depth of $0-30 \mathrm{~cm}$. The results of the analysis of soil organic-C content due to the rotation pattern with the legume ground covers in dry land maize farming were significantly different between rotation treatments (Figure 1).

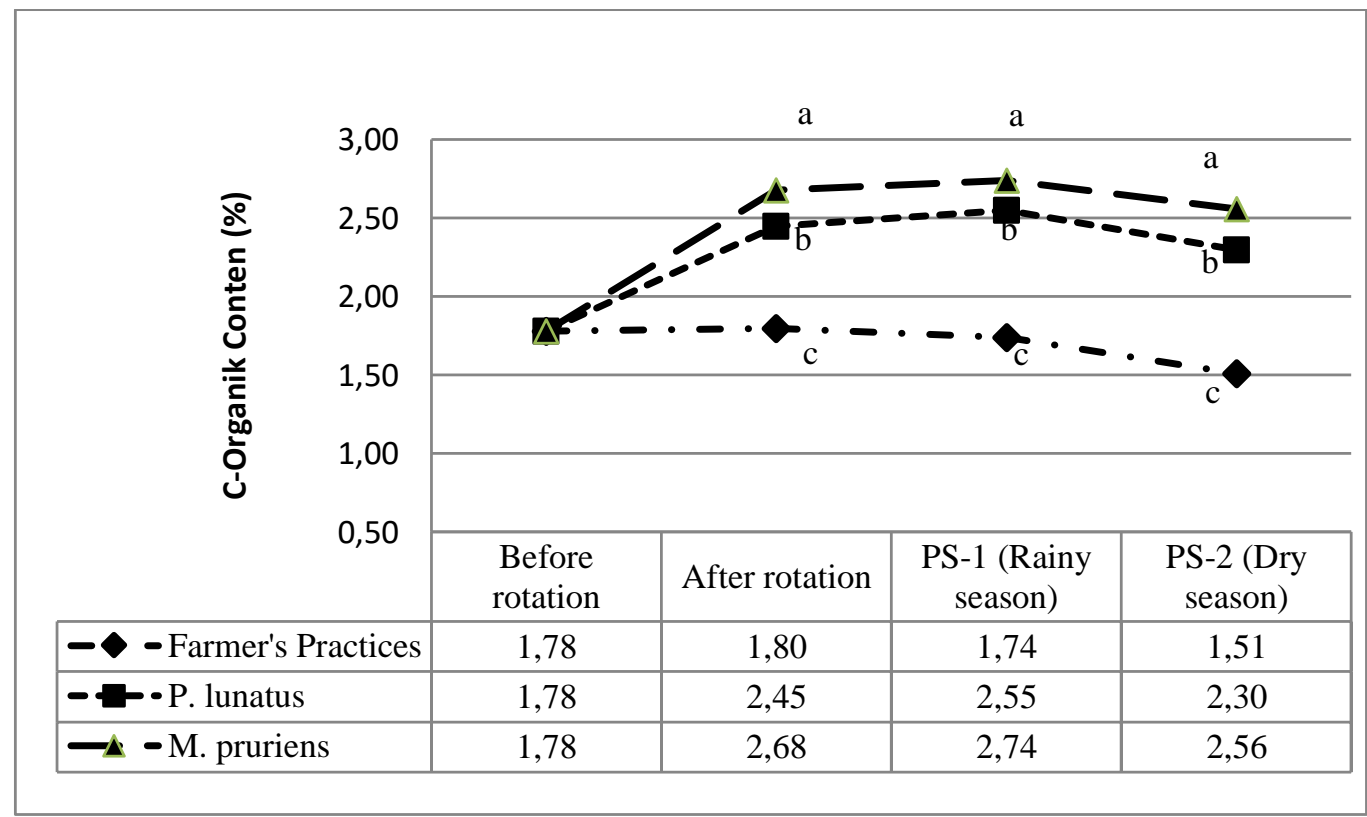

Fig. 1. Dynamics of soil C-Organic levels due to the practice of rotation patterns with legume ground covers in dry land maize farming

In Figure 1, it appears that the rotation pattern with the legume cover crop after corn planting increased soil organic C content compared to that without rotation (farmer practice). Soil organic $\mathrm{C}$ content in the rotation treatment with Mucuna pruriens significantly increased soil organic $\mathrm{C}$ content from $1.78 \%$ to $2.68 \%$ or an increase of $50.56 \%$. Rotation with Phaseolus lunatus also significantly increased organic $\mathrm{C}$ to $2.45 \%$ or an increase in organic $\mathrm{C}$ was $37.64 \%$, which were significantly higher than that without rotation (farmer pattern), with organic-C content of only $1.80 \%$.
Figure 2 shows that due to the rotation with the legume ground covers there had been a change in soil organic $\mathrm{C}$ content until the second planting season (MT2). The rotation pattern with Mucuna pruriens up to PS-2 decreased the levels of C-organic to $43.82 \%$ and with Phaseolus lunatus showed a decrease in C-organic to $29.21 \%$. This was different from the practical treatment of farmers (without rotation), which shows showed a decrease in C-organic content to $1.51 \%$ (low). 


\section{Dynamics of N, P, and K nutrients.}

In general, the rotation pattern treatment with legume ground covers significantly increased the macronutrients $(\mathrm{N}$, $\mathrm{P}$, and $\mathrm{K}$ ) in the soil. The results of soil analysis that were carried out 3 (three) times, namely at planting time (after immersing the legume biomass); at the end of harvest PS-1, and at the end of harvest PS-2, which are presented in Table 2.

Table 2 shows that there is a tendency to increase in soil macronutrients $(\mathrm{N}, \mathrm{P}$, and
K) due to rotation patterns with legume ground covers. The rotation pattern with Mucuna pruriens and Phaseolus lunatus showed higher change in macronutrient content during the two growing seasons compared to those without rotation. The content of total $\mathrm{N}$ in the soil were also varied. The highest total $\mathrm{N}$ content in rotation with Mucuna pruriens was $(0.35 \% \mathrm{~N})$ at planting maize and decreased in PS-2 to $0.21 \%$.

Table 2. Dynamics of soil N, P, and K nutrient content at the experimental site during the two growing seasons after rotation with legume ground covers

\begin{tabular}{|c|c|c|c|c|}
\hline \multirow{2}{*}{$\begin{array}{l}\text { Practice Pattern } \\
\text { Rotations }\end{array}$} & \multirow{2}{*}{$\begin{array}{l}\text { Sample } \\
\text { Measurement }\end{array}$} & \multicolumn{3}{|c|}{ Soil nutrient content } \\
\hline & & $\mathrm{N}(\%)$ & $\mathrm{P}(\mathrm{ppm})$ & $\mathrm{K}(\mathrm{mg} / 100 \mathrm{~g})$ \\
\hline \multirow{3}{*}{$\begin{array}{l}\text { Farmer's practice } \\
\text { (No Rotation) }\end{array}$} & post fallow & $0.17 \square 0.02$ & $6.67 \pm 0.90$ & $14.82 \pm 0.89$ \\
\hline & Harvest PS-1 & $0.14 \square \square 0.02$ & $6.12 \pm 0.90$ & $12.91 \pm 0.34$ \\
\hline & Harvest PS-2 & $0.12 \square 0.03$ & $4.81 \pm 0.41$ & $10.23 \pm 0.48$ \\
\hline \multirow{3}{*}{$\begin{array}{l}\text { Rotation with } \\
\text { Mucuna Pruriens }\end{array}$} & post fallow & $0.35 \square 0.03$ & $10.14 \pm 0.76$ & $29.23 \pm 0.66$ \\
\hline & Harvest PS-1 & $0.28 \square 0.03$ & $9.22 \pm 0.86$ & $25.22 \pm 0.57$ \\
\hline & Harvest PS-2 & $0.21 \square 0.02$ & $6.81 \pm 0.82$ & $22.21 \pm 0.90$ \\
\hline \multirow{6}{*}{$\begin{array}{c}\text { Rotation with } \\
\text { Phaseolus lunatus }\end{array}$} & & 0.31 & \multirow{2}{*}{$10.08 \pm 0.67$} & \\
\hline & post fallow & 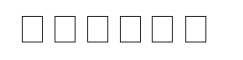 & & $27.83 \pm 0.53$ \\
\hline & & 0.25 & \multirow[t]{2}{*}{$9.18 \pm 0.81$} & \\
\hline & Harvest PS-1 & $\begin{array}{l}\square \square \square \square \square \\
\end{array}$ & & $24.82 \pm 0.52$ \\
\hline & Harvest PS-2 & 0.21 & $6.62 \pm 0.51$ & $21.62 \pm 0.80$ \\
\hline & & 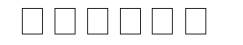 & & \\
\hline
\end{tabular}

The similar total $\mathrm{N}$ content condition was also shown in the rotation pattern with Phaseolus lunatus, which was $0.31 \%$ at planting and decreased in PS-2 to $0.21 \%$.

The content of $\mathrm{P}$ and $\mathrm{K}$ nutrients in the soilvaried, the highest $\mathrm{P}$ and $\mathrm{K}$ levels were shown by the rotation pattern treatment with
Mucuna pruriens and Phaesolu lunatus. At planting the $\mathrm{P}$ levels were $10.14 \mathrm{ppm}$ and 10.08 ppm, while $\mathrm{K}$ levels were 29.23 $\mathrm{mg} / 100 \mathrm{~g}$ soil and $27.83 \mathrm{mg} / 100 \mathrm{~g}$ soil respectively, which were higher than those of the farmer's practice (where $\mathrm{P}$ and $\mathrm{K}$ levels 
only reached $6.67 \mathrm{ppm}$ and $14.82 \mathrm{mg} / 100 \mathrm{~g}$ the amount of nutrients from fertilizers added soil respectively) at the end of PS-2.

\section{Agronomic nutrient efficiency}

The agronomical efficiency of analysis of the nutrient uptake efficiency of $\mathrm{N}$, nutrients can be determined by comparing the $\mathrm{P}$, and $\mathrm{K}$ are presented in Figure 2. number of nutrients transported by plants with

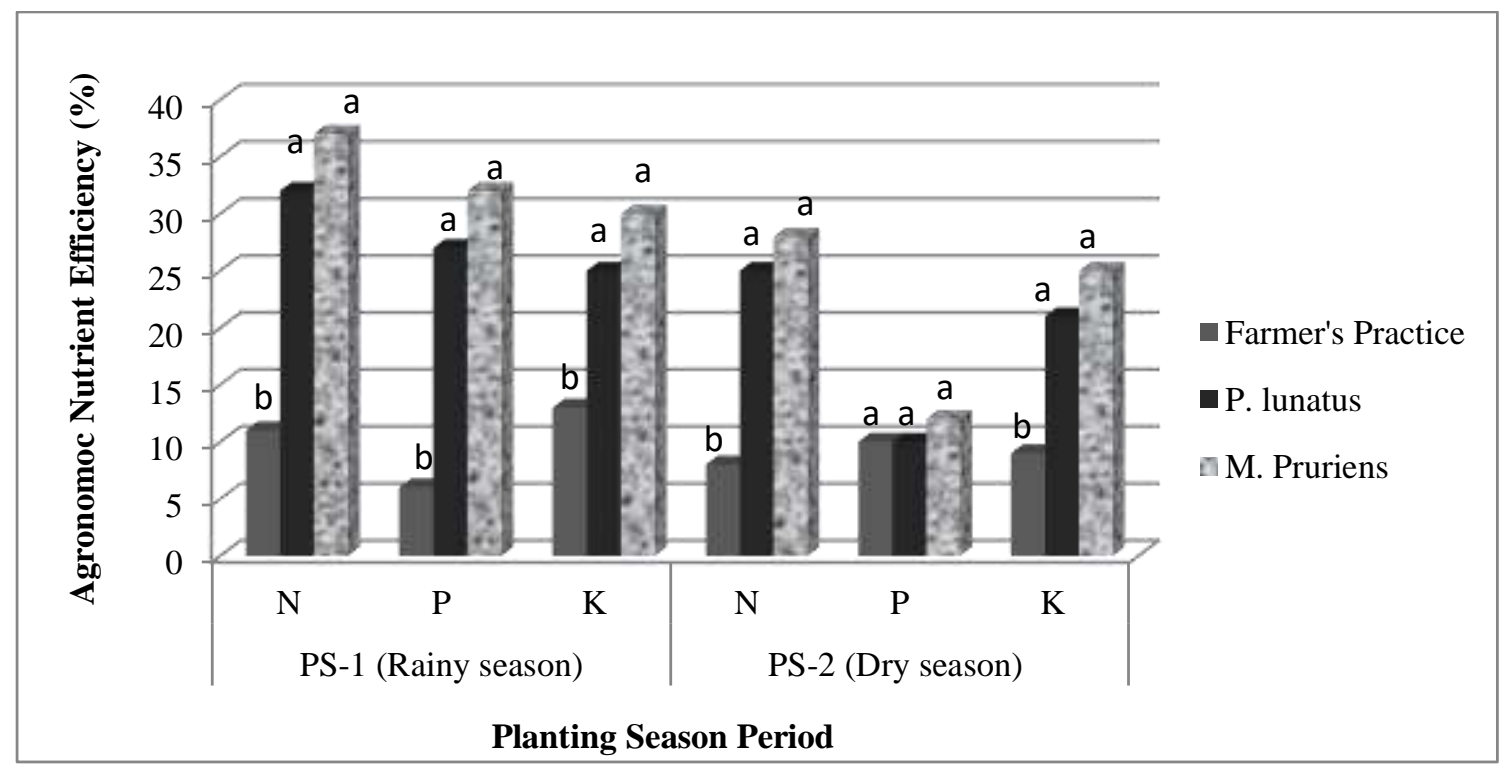

Fig. 2. Agronomic nutrient efficiency of $\mathrm{N}, \mathrm{P}$, and $\mathrm{K}$ maize in a rotation pattern practice with legume ground covers for two periods of the growing season

The efficiency of agronomic nutrients was tested to see the effect of rotation patterns with legume ground covers on the percentage of nutrient uptake and used by plants compared with the amount of nutrients from fertilizers added. Based on the analysis, it was known that the practice of the rotation pattern with the legume ground covers had an effect on the agronomic efficiency of $\mathrm{N}, \mathrm{P}$, and $\mathrm{K}$ nutrient uptake during the two growing seasons, as shown in Figure 2.

Figure 2 shows the application of the rotation pattern with the legume species of
Mucuna pruriens resulted in the highest nutrient agronomic efficiency during PS1 and PS2, respectively, $37 \%$ and $28 \%$ of $\mathrm{N} ; 27 \%$ and $17 \%$ of $\mathrm{P}$ and $30 \%$ and $22 \%$ of $\mathrm{K}$. Rotation with the species Phaseolus lunatus resulted in agronomic efficiency of $32 \%$ and $25 \%$ of $\mathrm{N} ; 27 \%$ and $17 \%$ of $\mathrm{P}$ and $25 \%$ and $19 \%$ of $\mathrm{K}$ respectively, which were higher than the farmer practice (without rotation), with less agronomic efficiency in both PS-1 and PS-2.

The efficiency of agronomic nutrients was tested to see the effect of rotation patterns 
with legume ground covers on the percentage of nutrient uptake and used by plants compared with the amount of nutrients from fertilizers added. Based on the analysis, it was known that the practice of the rotation pattern with the legume ground covers had an effect on the agronomic efficiency of $\mathrm{N}, \mathrm{P}$, and Knutrient uptake during the two growing seasons, as shown in Figure 2.

Figure 2 shows the application of the rotation pattern with the legume species of Mucuna pruriens resulted in the highest nutrient agronomic efficiency during PS1 and PS2, respectively, $37 \%$ and $28 \%$ of $\mathrm{N} ; 27 \%$ and $17 \%$ of $\mathrm{P}$ and $30 \%$ and $22 \%$ of $\mathrm{K}$. Rotation with the species Phaseolus lunatus resulted in agronomic efficiency of $32 \%$ and $25 \%$ of $\mathrm{N} ; 27 \%$ and $17 \%$ of $\mathrm{P}$ and $25 \%$ and $19 \%$ of K respectively, which were higher than the farmer practice (without rotation), with less agronomic efficiency in both PS1 and PS2.

\section{Corn yields}

The rotation pattern of the legume cover crop showed a significant effect on maize yields during the two growing seasons. The yields of dry kernel corn in PS-1 (rainy season) and PS-2 (dry season) is presented in Figure 3.

The rotation pattern with legumes of Mucuna prriens and Phaseolus lunatus significantly increased dry kernel corn yields, with 6.20 tonnes/ha and 5.52 tonnes / ha respectively in PS-1 but decreased to 5.24 tonnes/ha. and 4.68 tonnes/ha in PS-2 (Figure 3). However, they were still higher than those without rotation (where the maize yield only reached 3.16 tonnes/ha in PS-1 and 2.58 tonnes / ha in PS-2.

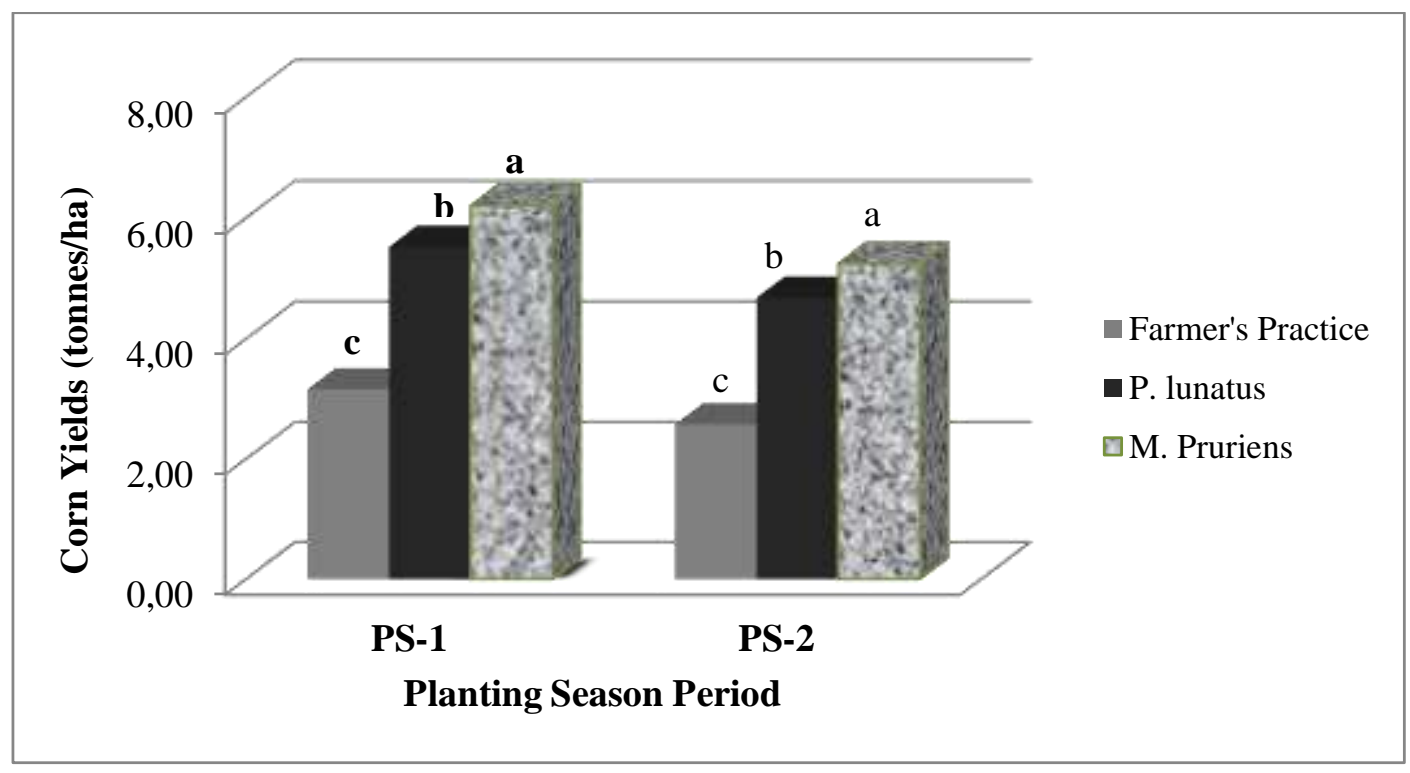

Fig. 3. Corn yield (tonnes/ha) in the practice of a rotation pattern with legume ground covers for two periods of the growing season 


\section{DISCUSSIONS}

It appears that the land rotation system in corn cropping showed significant effects on the dynamics of soil organic $\mathrm{C}$ content and $\mathrm{N}$, $\mathrm{P}, \mathrm{K}$ nutrients during the two growing seasons. Rotation with Mucuna pruriens and Phaseolus lunatus significantly increased the soil organic C content by $50.56 \%$ and $37.64 \%$ in PS-1 but PS-2 decreased in C-organic to $43.82 \%$ and $29.21 \%$ in PS-2. The increase in soil organic $-\mathrm{C}$ content was caused by the supply of organic matter of the two legumes planted during the fallow period (during the dry season) after which the biomass were returned to the land. Legume biomass is generally of a high quality which allows decomposition to take place naturally. The rotation pattern with legumes during the dry season will be slow, allowing the accumulation of more organic matter in the soil layer (Hairiah et al., 2006). The presence of organic carbon in the soil layer will would help increase aggregation, especially in soils with clay textures. Increasing soil aggregation had an effect on improving physical properties, which could lower bulk density and increase pore space and soil pore distribution (Stevenson, 1994; Wailiru and Lal, 2006).

Those condition was different from the practice of farmers (without rotation) who left the land open during the fallow period (dry season), in which the rate of decomposition of organic matter takes place faster due to high temperatures. In addition, the habit of dry land farmers transporting collected and carried the crop residues (straw) out of the land is a contributing factor to the reduced reserves and supply of soil organic matter. Burning of plant debris or straw and litter was also a condition that accelerated the loss of organic carbon from the soil system.

The rotation pattern with legume ground covers during the fallow period also significantly increased the $\mathrm{N}, \mathrm{P}$, and $\mathrm{K}$ nutrients in the soil and increased the efficiency of those agronomic nutrients. Those were due to the role of carbon contributed by the legume biomass which had undergone decomposition into humus colloid. The presence of humus colloids in the soil help the process of nutrient mineralization in the soil, becoming nutrients that easily available to plants in the form of ions (Stevenson). Agsary et al., (2020), stated that the substitution of organic fertilizers and biological fertilizers increase the efficiency of macro and micronutrient uptake in, due to an increase in physical fertility and the role of soil biology. Utomo's research, (1995) showed that the average efficiency of $\mathrm{N}$ fertilization for on land without tillage reached $37.8 \%$ when compared to intensive tillage which only reached $16.6 \%$ in the first planting season. This because intensive soil cultivation physical damage to the soil, 
namely the soil more porous so that many nutrients washed away. Meanwhile, farmer practices (Table 2 and Figure 3) show a decrease in nutrients and a decrease in nutrient uptake efficiency. This thought to be caused by low levels of organic carbon, which an impact on soil compaction, in poor aeration in the soil (Kusno and Rustaman, 2013; Kusumastuti et al., 2018).

This land management through a rotation system a solution for land. because easy and cheap. Implementing a rotation system with legumes during fallow protect the soil surface from direct light exposure and a large supply of quality organic matter. Its presence increase soil moisture and cause the soil to become and increase soil holding power to the water. The availability of water in the soil pores in the plant root layers become available for plant growth and also plays a role in the process of mineral weathering and nutrient solubility that made easily absorbed by plants.

\section{CONCLUSIONS}

Land management through a rotation system significantly increased soil organic C content by $50.56 \%$ and $37.64 \%$ compared to Farmer's practice (no rotation). The practice of land rotation system with with legumes ground covers can increase soil carbon, because in the long run it significantly increases the efficiency of agronomic nutrients ( $\mathrm{N}, \mathrm{P}$, and $\mathrm{K}$ nutrients) and yields during the two growing seasons. Conversely, the practice of farmers (without rotation) showed a decrease in soil carbon in PS-2, which resulted in reducing the efficiency of $\mathrm{N}$, $\mathrm{P}$ and $\mathrm{K}$ absorption.

\section{REFERENCES}

Agsary, D., M. Utomo, K. F. Hidayat, A. Niswati. (2020). Respon Serapan Hara Makro-Mikro dan Produksi Tanaman Jagung (Zea mays L.) Terhadap Pemupukan Nitrogen dan Praktik Olah Tanah Jangka Panjang. Journal of Tropical Upland Resources. Vol.02 (01): 46-59

Doran, J.W., Parkin, T.B. (1994). Defining and Assessing Soil Quality. p3-21. In: J.W. Doran, D.C. Coleman, D.F. Bezdicek, B.A. Stewart (eds.), Defining Soil Quality for a Sustainable Environment. SSSA Spec. Pub. No. 35, Soil Sci. Soc. Am., Am. Soc. Argon., Madison, WI

Gomez, A.A dan K.A. Gomez. (2007). Prosedur Statistik untuk Penelitian Pertanian. Universitas Indonesia. Cetakan kedua.

Finck, A. (1992). Fertilizer and their efficient use. IFA Word Fertilizer Use Manual.

Hairiah K, H Sulistyani, D Suprayogo, Widianto, P Purnomosidi, RH Widodo and M Van Noordwijk. (2006). Litter layer residence time in forest and coffee agroforestry systems in Sumberjaya, West Lampung. Forest Ecology and Management, 224:45-57

Handayanto, E., Cadisch, G., Giller., K. E. (1997). Regulating N Mineralization from Plant Recidues by Manipulation of Quality. P.175-185. In: G. Grdisch and K.E. Giller (eds.). Driven by nature plant litter quality and decompocition. CAB International, Wallingford. 
Islam, K.R., Weil. (2000). Soil quality indicator properties in mid-atlantic soils as influenced by conservation management. J. Soil and Water Cons. 55 (1): 69-78

Jagadeeswaran, R, V. Murugappan, and M. Govindaswamy. (2005). Effect of Slow Release NPK Fertilizer Sources on the Nutrient use Efficiency in Turmeric (Curcuma longa L.). World Journal of Agricultural Sciences 1 (1): 65-69.

Kasno, A.n Tia Rostaman. (2013). Serapan Hara dan Peningkatan Produktivitas Jagung dengan Aplikasi Pupuk NPK Majemuk. Jurnal Penelitian Pertanian Tanaman Pangan Vol. 32 (3).

Kusumastuti, A., Fatahillah., A. Wijaya., Y. Sukmawan. (2018). Pengaruh Sistem Olah Tanah dan Residu N Tahun ke29 pada Beberapa Sifat Kimia Tanah dengan Tanaman Indikator Leguminosa. Journal of Applied Agricultural Sciences 2 (1): 20-29.

Larson, W.E., Pierce, F.J. (1994). The dynamics of soil quality as a measure of sustainable management. p.37-51. In: J.W. Doran, D.C. Coleman, D.F. Bezdicek, and B.A. Stewart (eds.), Defining Soil Quality for a Sustainable Environment. SSSA Spec. Pub. No. 35, Soil Sci. Soc. Am., Am. Soc. Argon., Madison, WI.

Liu, X., Herbert, S.J., Hashemi, A.M. Zhang, X., Ding, G. (2006). Effects of agricultural management on soil organic matter and carbon transformation-a review. Plant. Soil Environ. 56(12): 531-543

Matheus, R. (2014). Peran Legum penutup tanah tropis dalam menimgkatkan simpanan karbon organik tanah dan Kualitas tanah serta Hasil jagung (Zea maiz L) di lahan kering. Disertasi. Universitas DUdayana. Dempasar

Matheus, D. Kantur, N. Bora. (2018). Innovation of The Fallow System with
The Legume Cover Crop A Season for Improved Physical Properties of Soil Degradated On Dryland Farming. Journal of Scientific \& Technology Research. Vol. 7 (7): 107-111. https://www.ijstr.org/research-paperpublishing.php?month=july2018

Matheus, R. (2019). Skenario Pengelolaan Sumber Daya Lahan Kering: Menuju Pertanian Berkelanjutan. Deepublish. Yogyakarta.

Milkha S. Aulakh, T. S. Khera, John W. Doran, and Kevin F. Bronson. (2001). Managing Crop Residue with Green Manure, Urea, and Tillage in a RiceWheat Rotation. Soil Sci. Soc. AM. J., Vol. 65.

Olson, K.R., Ebelhar, S., Lang, A., James, M. (2010). Cover crop effects on crop yields and soil organic carbon content. Soil Science. 175:89-98

Rahman, M.M. (2013). Nutrient-Use and Carbon-Sequestration Efficiencies in Soils from Different Organic Wastes. In: Rice and Tomato Cultivation. Comm. in Soil Sci. and Plant Anal. 44 (9): 1457-1471

Sulaeman, Suparto, Eviati. (2005). Petunjuk Teknis Analisis Kimia Tanah, Tanaman, Air dan Pupuk. Balai Penelitian Tanah. Badan Penelitiandan Pengembangan Pertanian. Departemen Pertanian. Bogor.

Stevenson FJ. (1994). Humus Chemistry. Genesis, Co mposition, Reaction. 2nd ed. John Wiley and Sons. New York

Utomo, M. (2015). Tanpa Olah Tanah, Teknologi Pengelolaan Pertanian Lahan Kering. Penerbit Graha Ilmu. $157 \mathrm{hlm}$.

Wairiu, M. and Lal, R. (2006). Tillage and land use effects on soil microporosity in Ohio, USA and Kolombangara, Solomon Islands. Soil Till. Res. 88: 8084. 